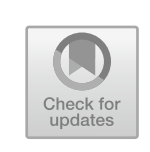

\title{
Introduction: Infectious Animals and Epidemic Blame
}

\author{
Christos Lynteris
}

The resurgence of zoonotic and vector-borne diseases in the course of the twenty-first century (SARS, bird flu, MERS, Ebola, Zika and Nipah) has fostered and complicated scientific framings of non-human animal and insect hosts and vectors of infectious diseases as 'epidemic villains'. No longer seen as mere reservoirs or spreaders of disease, but as the very ground where new pathogens emerge, non-human animals are today conceived as the incubators of existential risk for humanity. Visually, ideologically and affectively inflected, these framings are often developed in the context of epistemic lacunas: a lack of scientific certainty about the true reservoir of SARS or Ebola is thus compensated by systematic and widespread representations of few select animals, such as bats or civet cats, as epidemiological 'rogues'. ' These framings are furthermore complicated by what has been described by Carlo Caduff as the 'mutant ontology' of viral pathogens carried by these animals and by the broader epistemological framework

\footnotetext{
C. Lynteris $(\bowtie)$

Department of Social Anthropology, University of St Andrews, St Andrews, Scotland, UK e-mail: cl12@st-andrews.ac.uk

(c) The Author(s) 2019

C. Lynteris (ed.), Framing Animals as Epidemic Villains, Medicine and Biomedical Sciences in Modern History, https://doi.org/10.1007/978-3-030-26795-7_1
} 
of 'emerging infectious diseases' (EID), which configures the rise of new diseases as carrying with it a potential for human extinction. ${ }^{2}$

This volume examines the history of the emergence and transformation of epidemiological and public health framings of non-human disease vectors and hosts across the globe. Providing original studies of rats, mosquitoes, marmots, dogs and 'bushmeat', which at different points in the history of modern medicine and public health have come to embody social and scientific concerns about infection, this volume aims to elucidate the impact of framing non-human animals as epidemic villains. Underlining the ethical, aesthetic, epistemological and political entanglement of non-human animals with shifting medical perspectives and agendas, ranging from tropical medicine to Global Health, the chapters in this volume come to remind us that, in spite of the rhetoric of One Health and academic evocations of multispecies intimacies, the image and social life of non-human animals as epidemic villains is a constitutive part of modern epidemiology and public health as apparatuses of state and capitalist management. ${ }^{3}$ Whereas the above approaches (including microbiome studies, and 'entanglement' frameworks in medical anthropology) do contribute to a much-needed shift in the intellectual landscape as regards the impact of animals on human health, their practical and political limitations are revealed each time there is an actual epidemic crisis. Then, all talk of One Health, multispecies relationships and partnerships melts into thin air, and what is swiftly put in place, to protect humanity from zoonotic or vector-borne diseases, is an apparatus of culling, stamping out, disinfection, disinfestation, separation and eradication; what we may call the sovereign heart of public health in relation to animal-borne diseases. ${ }^{4}$ For the maintenance and operation of this militarised apparatus, the framing of specific animals as epidemic villains is ideologically and biopolitically indispensable, even when blame of the 'villain' in question lacks conclusive scientific evidence (see Thys, this volume). Going against the grain of scholarship that in recent years has sought to portray the vilification of animals as hosts and spreaders of disease as a thing of the past, Histories of Non-Human Disease Hosts and Vectors aims to illuminate the continuous importance of this ideological and biopolitical cornerstone of modern epidemiology and public health.

\section{VERmin AND Noxious Animals}

Representations of animals as enemies, antagonists or sources of danger have, in different forms, shapes and degrees, been part and parcel of human interactions with the non-human world across history. It is, however, only 
at the turn of the nineteenth century that, as a result of bacteriological breakthroughs, non-human animals began to be systematically identified and framed as reservoirs and spreaders of diseases affecting humans. To take one famous example, before the end of the nineteenth century, rats were not believed to be carriers or spreaders of plague or any other infectious disease. ${ }^{5}$ Whereas rats had long been considered to be damaging to human livelihood, due to consuming and spoiling food resources, their only redeeming characteristic was, erroneously, widely believed to be their supposed disease-free nature. ${ }^{6}$ Hence while mid-seventeenth-century plague treatises noted the rat's destructive impact on fabrics and food, no mention of its connection with the disease was made. ${ }^{7}$ Equally, two centuries later, when in 1849-1850 British colonial officers in India observed that, at the first sight of rat epizootics, Garhwali villagers fled to the Himalayan foothills in fear of the 'Mahamari' disease, they dismissed this behaviour as merely superstitious. ${ }^{8}$

However, the bacteriological identification of rats as carriers of plague or mosquitoes as carriers and spreaders of yellow fever and malaria, at the end of the nineteenth century, was itself enabled and indeed complicated by an already-existing stratum of signification which, by the mid-seventeenth century, had led to the introduction of new symbolic, ontological and legal frameworks of thinking about animals as 'vermin'. Vermin, in Mary Fissell's definition, 'are animals whom it is largely acceptable to kill', not because of some inherent characteristic they possess, but because, in specific historical contexts, 'they called into question some of the social relations which humans had built around themselves and animals'. Paraphrasing Fissell, we may say that, arising in early modern Europe, the category 'vermin' problematised animals which devoured or destroyed the products of human labour and the means of human subsistence in terms of an agency or intentionality that confounded human efforts to control them. Departing from the structuralist influences of Mary Douglas, which dominated animal studies in the 1980s (see, for example, Robert Danton's work on the great cat massacre in 1730 France), and from Keith Thomas' 'modernisation' reading of vermin as simply animals that were of no use in an increasingly utilitarian world, Fissell's discourse analysis of popular texts on vermin from seventeenth-century England was the first to dwell in the social historical reality of the emergence of this notion. ${ }^{10}$ However, more recent studies have opposed Fissell's idea that what made vermin a threat to 'human civility' was their perceived 'greed and cunning', or their overall 'trickster' character. ${ }^{11}$ Lucinda Cole's recent monograph Imperfect 
Creatures argues that, 'what made vermin dangerous was less their breedspecific cleverness or greed than their prodigious powers of reproduction through which individual appetites took on new, collective power, especially in relation to uncertain food supplies'. ${ }^{12}$ The two approaches are not mutually exclusive. Indeed, if approached anthropologically, they point to an entanglement between symbolic and economic aspects of vermin as threats to 'social integrity', something that is further supported by the association of vermin at the time with vagrancy and the poor. ${ }^{13}$

Medical historians have in turn noted the association of vermin with miasma in disease aetiologies and public health practices of early modern Europe, especially in times of epidemics when extensive legislation against them and prescriptions for their destruction are recorded. ${ }^{14}$ This was particularly the case in the context of plague outbreaks that had long been associated with 'putrid' and 'corrupt' vapours, which certain animals, like dogs, pigs, cats and poultry (and their excrements and carcasses), were believed to emanate. ${ }^{15}$ As in the late Middle Ages, the fear of pestilential miasmata emanating from offal and other meat products had led to the spatial regulation of butchery in England and other parts of Europe (CF concerns with 'bushmeat' in relation to Ebola; Thys, this volume), William Riguelle has shown that, in the course of the seventeenth century, concerns with 'noxious' animals played an important role in instituting limits of where these could be kept and where they could be allowed to roam in urban environments. ${ }^{16}$

The idea of miasma would continue to impact medical thinking into the nineteenth century. As a part of ontologies that escape both the straightjacket of recent anthropological classifications and classical medicalhistorical dichotomies of contagionism/anti-contagionism, the idea of miasma was malleable, adaptable and ambiguous enough to be compatible with, rather than antagonistic to, that of infection and contagion. ${ }^{17}$ However, as new medical and biopolitical challenges arose in the context of colonial conquest, the problematisation of animal-derived miasma or 'febrile poison' gave way to concerns about the climate as the driving force of epidemic disease. ${ }^{18}$ Thus while the dawn of bacteriology, by the 1870 s, did not introduce understandings of animals as sources of disease ex nibilo, it did mark a drastic return to this idea, and, at the same time, led to a significant conceptual shift as regards the ontology of the diseases transmitted, and the mechanism involved in this transmission. ${ }^{19}$ This transformation was catalysed by an intense medical, economic and political interest and concern over cattle epizootics, which, as historians have shown, catalysed 
both the emergence of veterinary medicine and the medicalisation of animals across the globe in the second half of the century. ${ }^{20}$ As regards infectious diseases affecting humans, the medicalisation of non-human animals and their transformation into 'epidemic villains' involved an interlinked, two-part framing of their epidemiological significance: on the one hand, as spreaders and, on the other hand, as reservoirs of diseases.

\section{DISEASE SPREADERS}

The historiography of the identification and study of non-human animals as spreaders of infectious diseases has for some time now stopped being the foray of heroic biographies of men like Ronald Ross, Paul-Louis Simond or Carlos Chagas. Focused on the social, political and epistemological histories of scientific studies of zoonosis and vector-borne diseases, historians, anthropologists and STS scholars have underlined the ways in which, within epidemiology, bacteriology and parasitology, non-human animals constituted active agents in complex networks of power and knowledge, and how they assumed different epistemic value in diverse colonial and metropolitan contexts. ${ }^{21}$ Framed as spreaders of infectious diseases, animals also came to play an important role in what Charles Rosenberg has famously described as the dramaturgy of epidemics. ${ }^{22}$ Assuming a protagonistic role in a series of epidemic and public health dramas, animals came to be seen as the ultimate source of disease outbreaks. No longer simply a nuisance or 'pests', the transformed image of a series of animals (mosquitos, rats, ticks, lice and flies in particular) as enemies of humanity was invested with militaristic tropes and colonial moralities. These animals formed as it were a global repertoire of disease spreaders, while at the same time assuming importantly diverse local forms, often in interaction with concerns and social imaginaries about other, regionally specific, disease hosts and vectors (beetles, bats, sandflies, etc.). While it is not in the scope of this Introduction to map these 'glocal' interactions, Deborah Nadal's chapter in this volume provides a detailed picture of the longue durée of dogs as spreaders of rabies in India.

Nadal's chapter underlines the complex and important semiotic and ontological workings and re-workings on dogs as spreaders of rabies from colonial India to our times. With dog-borne rabies being recognised as an important public health problem across the globe since the 1870s, in India, where rabies is endemic, human understandings of the particular zoonosis were linked to practices of classifying dogs. For British colonials, distinguishing between rabies-prone and rabies-impervious dogs was key to the 
imperial project of mastery over both Indian society and 'nature'. Within the confines of tropical medicine and its biopolitical imperatives, the management of rabies made crucial the definition of dog-human relations in terms of ownership. Believed to be able to spontaneously develop rabies, for the British, 'ownerless' dogs presented a distinct danger for the colony. Seen as the source of infection amongst owned dogs (which were considered unable to develop spontaneous rabies), these animals, Nadal argues, challenged Victorian morality and were associated with two key notions: on the one hand the notion of 'stray', with its overtones of vagrancy, and, on the other hand, the notion of the 'pariah'-an Anglicised caste term used by British colonials to refer to outcaste or untouchable communities. At the heart of these classifications lied ideas about domesticity and wildness, as well as a pervasive social hierarchical mentality. Perceiving street life in general as a threat to colonial rule grouped dogs of distinct social status and social life under one, infectious category. Transforming 'strays' from 'vermin' and 'nuisance' into epidemic villains that should be sacrificed in the name of human health was not, however, a frictionless process but, as Nadal shows us, one that embroiled Indian society in debates about the value of life and compassion (led by both anti-vivisectionists and Mahatma Gandhi). After 1947, 'catch-and-kill' of dogs for the control of rabies continued unabated but also involved Indian society in renewed debate involving civil society activists, animal welfarists and political parties. In Nadal's reading, these dog-related conflicts underlined a lingering problem pertaining to the classification of dogs vis-à-vis rabies: the persistence of the term 'stray' (inclusive of its 'pariah' associations). The solution since 2001, Nadal argues, has been the emergence of a discourse around 'street dogs', which has marked a shift towards an accommodation between different attitudes towards the particular animals, allowing for the concept that they can be both masterless and hygienic.

Nadal's chapter thus points out that, at the same time as what we may call high-epidemiology redefined experiences of non-human animals as spreaders of disease, it also instituted regimes of hygienic hope. Envisioning and putting in place programs of increasing separation between humans and non-human disease vectors became the hallmark of public health from 1900 onwards. Whether this involved rat-proofing, DDT spraying, mosquito nets, the cleaning of streets from stray dogs or the drying of swamps, this sanitary-utopian aspiration to liberate humanity of zoonotic and vectorborne diseases was based on a vision of universal breaking of the 'chains of infection'; a separation and, at the same time, unshackling of humans 
from disease vectors that was aimed at confining pathogens in the animal realm. ${ }^{23}$ In this way, whereas separation from animals was seen as a sufficient means of protection of humans from zoonotic and vector-borne diseases, animals themselves were defined as ultimately hygienically unredeemable - they were, in other words, rendered indistinct from disease. Hence, the naturalist ontology of the Enlightenment, which in Philippe Descola's anthropological model defines humans and animals as unified under the rubric of nature, was unsettled by a radical divide that saw disease as a mode of being which was only inherently proper to non-human animals, and only tentatively, or, as sanitary utopians would have it, temporarily, part of the human species. ${ }^{24}$

Sayer's chapter in this volume focuses on the 1910-1911 plague outbreak in Freston (Suffolk, UK) — the last outbreak of plague in the history of England - and excavates the epistemological, political, class and colonial history of such a regime of prevention and hope. Analysing what she calls 'the vermin landscape' of the outbreak, Sayer focuses on non-human animal actors so as to show that, in spite of the widespread epidemiological acceptance of the rat flea (Xenopsylla cheopis) as the true spreader of plague, ideas about locality and class created a medico-juridical matrix where it was the rat that constituted the main object of scientific investigation and public health intervention. Situating the Suffolk outbreak both within the third plague pandemic and within British Imperial science politics, Sayer stresses the ways in which Suffolk was connected to India, as the prime locus of the pandemic and of plague science in the Empire. As the outbreak in Suffolk was experienced as an echo of the ongoing devastating epidemic in India, the rat became an object of epidemiological concern and fear. What if infected rats moved from the rural hotspots of the epidemic into urban areas, transforming them into the equivalents of plague-ravaged Bombay on English soil? Such fears were fostered not just by the perceived natural traits of rats (as invasive of migratory animals), but also through their association with the rural poor. Tapping into complex imaginary registers involving Victorian systems of class-related disgust, the English rural idyll, and the image of 'the labourer's country cottage $[. .$.$] as literal and figurative repre-$ sentation of the state of the nation', Sayer argues that, 'because this rested in turn on the state of the rural labouring class, and that class were said here to be unsanitary and their cottages invaded by rat and plague, the Indian racial Other therefore ghosted a new category of (dead) undeserving poor'. As epidemic villains, in the eyes of epidemiologists and public health authorities, rats Indianised the dwellings of rural labourers in Suffolk. As 'plague 
was equated with "rat plague", plague also became Indian plague, and in turn necessitated control measures and legislation aimed at 'codif[ying] the rat in law and normalis[ing] its destruction'. Formulated around an entanglement of class and interspecies relations, the Suffolk plague crisis led, on the one hand, to an increasing medico-juridical investment of the rat in England, while, on the other hand, to a systematic neglect of 'the hares, cats, dogs that featured in gamekeepers' and labourers' narratives of the disease'. Identifying and investing on a non-human epidemic protagonist (the rat) led to, and indeed required, a disinvestment and neglect of other species involved in the spread of the disease, and-perhaps most crucially-to overlooking the ecological complexity of disease persistence and transmission between different species in any given ecosystem. The Rats and Mice (Destruction) Act 1919, 'which tasked every British citizen with a legal obligation to remove rats from their property', was the pinnacle of the configuration of the rat as an epidemic villain in England and of the institutionalisation of sanitary regimes of hope as regards the prevention of animal-borne infection.

Having conquered the globe by the mid-1920s, this regime of prevention and hope came to an end with the dawn of the emerging infectious diseases framework in the early 1990s, when scientists began to focus on processes leading to new diseases, hitherto of non-human animals, infecting humans and to the 'specie-jump' processes (so-called spillover) leading to this phenomenon: 'Rather than revolving around already-existing pathogens and how they circulate in specific ecological contexts, the focus on emergence required a shift of attention to what we may call "viral ontogenesis". ${ }^{25}$ Over the past 30 years, the rise of 'emergence' as the central framework of studying and understanding infectious diseases has led to a radical shift of scales and a reinvestment on zoonotic diseases that has been tied to a shift away from prevention towards preparedness. ${ }^{26}$ This is a regime of biosecurity that, as anthropologists like Andrew Lakoff, Frédéric Keck and Carlo Caduff have shown, is based on the anticipation of an unavoidable pandemic catastrophe, and which sets in place technologies of biosecurity that have come to increasingly dominate the realm of Global Health. ${ }^{27}$ Envisioned as inevitable and catastrophic, 'emergence' has thus radically transformed the status of animals as epidemic villains. On the one hand, whereas in the sanitary-utopian framework of highepidemiology, animals were considered to be isolatable carriers of disease, in the EID framework infection is rendered inevitable. And, on the other 
hand, whereas for the sanitary-utopian framework, animal-human infection posed a limited threat to humanity, for EID it poses an unlimited one, or to be precise one associated with existential risk. It is telling that the mytho-historical event defining the conceptual horizon of the sanitaryutopian framework was the Black Death. Believed by 1900 to have been rat-borne bubonic plague, the fourteenth-century pandemic was used by moderns as a key cautionary tale, and at the same time as a potent medical metaphor: Black Death was something that could 'return' (as hundreds of reports and news items made clear during the third plague pandemic) but whose impact would be effectively limited by grace of modern medicine and sanitation. On the other hand, as Caduff has shown, the mytho-historical event defining the conceptual horizon of EID is the 1918 flu pandemic. ${ }^{28}$ The political ontology of this event for our contemporary pandemic imaginary is distinctly different from that of the Black Death for the early-tomid-twentieth-century public. For, as every contemporary epidemiological report and news broadcast makes clear, were an event like 'the Spanish Flu' to occur again today, globalisation and modern transport would transform it to an event of human extinction proportions; something not only nonpreventable, but whose control, once it has begun, is not guaranteed. Both of these mytho-historical events have non-human animals at the heart of their causation narrative: the Black Death (at least so scientists believed at the time) rats, while the 1918 flu birds, probably chicken. However, while the sanitary myth of origin of the Black Death portrayed the rat as an ancient enemy of humanity whose days were numbered due to the advancement of science, the EID myth of origin frames chicken as just one example of a host of unknown species from which the 'killer virus' may emerge and against which the only action we can take is being prepared.

Séverine Thys' chapter in this volume explores the consequences of the EID approach to non-human animals, as it applied to 'bushmeat' in the context of the recent Ebola epidemic in West Africa (2014-2016), with a focus on the impact of epidemiological and public health framings of 'bushmeat' hunting, butchering and consumption. Especially affecting 'forest people' in Macenta, Guinea-Conakry, the framing of a fluid host of animals as the source of epidemiologically illicit meat relies on persistent colonial tropes that imagine the 'tropical jungle' as an originally natural realm whose disturbance by human activity leads to the emergence of killer viruses. ${ }^{29}$ Rehearsed time and again in films like Outbreak (1995), this mortal link between nature and culture, Thys reminds us, is currently being 
mediated by the figure of the bat-the in-between figure of a 'rogue' animal, which, James Fairhead has shown, is being increasingly deployed as an epidemiological bridge in several zoonotic scenarios (Ebola, MERS, SARS). ${ }^{30}$ Thys follows other anthropologists in pointing out that this insistence on 'bushmeat' and contact with fruit-bats frames local cultures as pathogenic, in line with Paul Ewald's notion of 'culture vectors', and thus 'obscure[s] the actual, political, economic, and political-economic drivers of infectious disease patterns'. ${ }^{31}$ Framed in terms of a 'transgression of species boundaries', Ebola spillover events are thus pictured as resulting from a life led according to 'traditional' (and the implication is irrational) classificatory systems that fail to maintain 'us vs. them' boundaries. Replete with visual and affective structures of disgust, this view, Thys argues, is not challenged by the One Health framework, which 'should provide a more nuanced and expanded account of the fluidity of bodies, categories and boundaries' so as to 'generate novel ways of addressing zoonotic diseases, which have closer integration with people's own cultural norms and understandings of human-animal dynamics'. ${ }^{32}$ Key to this, according to Thys, is to recognise and examine the historically dynamic nature of these classificatory and more broadly ontological systems (a view shared by Nadal, this volume), and the explanatory models with which they are entangled. Thys outlines the complex matrix of uses of non-farmed meat in the region (for nourishment, medicaments, trophies, etc.) and their transformation under the weight of regional and global commodity market networks. One may add that what is often neglected is the fact that 'bushmeat' was used by colonial authorities as a reward to local communities; in Angola, for example, the Portuguese rewarded local communities with 'bushmeat' for rat-catching in the colonial power's effort to contain plague during the 1930s. ${ }^{33}$

The political investments of non-human animals as disease spreaders are further explored in Gabriel Lopes' and Luísa Reis-Castro's chapter in this volume on the history of the Aedes aegypti mosquito in modern Brazil. Following the social life of the particular mosquito species from the 1950s until today, Lopes and Reis-Castro stress that, while recognising that it has always constituted an 'epidemic villain', we need to pay closer attention to the particular diseases to which this villainous character has been linked to, and to the corresponding political system under which this identification has been undertaken, over the course of modern Brazilian history. At the beginning of the twentieth century, Aedes aegypti was associated with 'underdevelopment' as a key overarching ailment of Brazil, with 'the 
image of a plagued country swarming with mosquitoes' filled with yellow fever playing an important role in bringing health under the rubric of the state and its modernising agenda. Lopes and Reis-Castro follow Gilberto Hochman's classic work on the linkage between sanitation and nationbuilding in Brazil in stressing that what began as a project of 'civilizing the tropics' by eliminating yellow fever across the country transformed by the early 1930s into a more modest programme of preventing outbreaks in urban centres. ${ }^{34}$ By contrast to the liberal nation-building sanitary-utopian visions of Oswaldo Cruz and his collaborators in the first decades of the twentieth century, in the second half of the 1980s a renewed focus on Aedes aegypti was underscored by the politics of democratisation, following the end of the 21-year-long military dictatorship in 1985. As by April 1986 it had become identified with dengue fever, as a new disease to plague urban 'areas marked by racialised histories of state abandonment and violence', the Aedes aegypti became associated with a disease that was not as lethal as yellow fever, and which bore with it the sign of social, political and economic restitution. As public health had been the pejorative of left-wing and other democratic forces during the last decade of the dictatorship, calls to control dengue-carrying Aedes aegypti as an embodiment of state violence and neglect contributed to the success of the 'sanitary reform movement' and the establishment, in 1988, of Brazil's Sistema Unico de Saude.

Lopes and Reis-Castro then turn their attention to the latest incarnation of Aedes aegypti as a spreader of the Zika virus. Unfolding during the years of the impeachment (or judicial coup, depending on one's point of view) against Dilma Rousseff, the appearance of Zika in Brazil involved Aedes aegypti in an international emergency. Lopes and Reis-Castro examine the political struggles around Zika-related mosquito control and argue that, focused on social inequality and the 'uneven effects of climate change', this new framing of the Aedes aegypti on the one hand continues a longestablished practice of problematising it as a disease vector with specific political and political-economic parameters, while, on the other hand, introducing important gender-related critiques of public health. Hence, while the authors claim that, 'the specific kind of virus in mosquitoes' bodies shaped what kind of epidemic villain the mosquito became', they also stress that, 'the mosquito as a vector carried not only three epidemiologically distinct viruses but very different political desires, struggles, and debates'.

Focusing on the recent Zika crisis, in their chapter to this volume Gustavo Corrêa Matta, Lenir Nascimento da Silva, Elaine Teixeira Rabello and 
Carolina de Oliveira Nogueira in turn argue that the focus on mosquitoes' guilt and on the technological strategies developed to control these vectors unfolded within a context of profound political instability, and at the same time of epistemic uncertainty regarding key epidemiological traits of the disease. Framing Aedes aegypti as epidemic villains in this context, diverted attention from issues of social, economic and environmental injustice and inequality that were driving determinants of the outbreak, and legitimised the absence of governmental measures regarding the latter in response to the epidemic. The 'enactment of a global enemy, Aedes aegypti, as the villain of the epidemic' thus allowed the Brazilian government to paint an all-too-familiar and deceptive picture of a Promethean struggle of the country as a unified whole (notwithstanding its enormous and often violent class, race, gender and ideological discrepancies and antagonisms) against a vile creature, which was solely held responsible for the disease. Drawing on critical medical anthropological perspectives, Matta et al. thus underline the structural violence inherent in both the discourse of epidemic villains and in the policies built and legitimated by this discourse. Brazil's mosquitocentred policy in the face of Zika, financially, politically and morally boosted by the declaration of Public Health Emergency of International Concern (PHEIC) by the WHO, relied on a securitisation framework that rhymed well with the broader neoliberal turn of the country and mobilised the image of the mosquito as a public enemy to create a spectacle of national unity that obscured iniquities, poverty, the skin colour of those bitten by mosquitoes, the house and streets where these fly, and the environment where they lay their eggs'.

\section{DiseAse RESERVOIRS}

As Mark Honigsbaum has shown, disease ecology frameworks, arising in the USA in the 1930s, framed non-human animals not simply as spreaders of infectious diseases but also as their 'reservoirs'. ${ }^{35}$ The 'great parrot fever epidemic' of 1929-1930 involved pet parrots in an epidemic panic across the globe, with a particular focus in the USA. As readers of the colonialist bande dessine exemplar, Tintin in the Congo (published in the shadow of the epidemic in 1931), may remember, psittacosis (caused by Chlamydia psittaci) is a zoonotic disease carried by parrots and parakeets that can infect humans. ${ }^{36}$ However, for Karl F. Meyer, a key contributor to the development of disease ecology, the ability of parrots and parakeets (popular pets at the time in the USA) to be asymptomatic carriers of the disease posed 
a more important problem that the immediate epidemic crisis; especially, Honigsbaum explains, as ' $[t]$ hese latent infections were a particular problem in California where during the Depression many people supplemented their incomes by breeding parakeets in backyard aviaries'. ${ }^{37}$ The discovery that psittacosis was not simply an 'exotic' disease imported to the USA by parrot traders, but one that had established itself endemically in American aviaries transformed the structure of epidemic blame from one focused on an outbreak to one focused on an endemic and, at the same time, from one revolving around an exotic invasion to one regarding unhygienic infrastructures at home. More profoundly, it also contributed to a shift towards a reframing of animal-borne disease in terms of disease ecology, a process which involved several decades of studies and interdisciplinary exchanges, but was ultimately triggered by an integration of Charles Elton's pathbreaking understanding of animal zoology in the realm of epidemiology. ${ }^{38}$

What is less well recognised historically is that the notion of the reservoir had a long history in epidemiological reasoning predating disease ecology. Rats in particular were suspected, from as early as 1900 , as not only spreading plague (via their flea, Xenopsylla cheopis) but as also contributing to the maintenance of persistence of the disease in given urban settings. ${ }^{39}$ Indeed, Elton's interest in the role of disease in the regulation of animal populations was itself stimulated by earlier Russian and Chinese studies of the Siberian marmot as a host of plague in the Inner Asian steppes. ${ }^{40}$ In Chapter 2 of this volume, Christos Lynteris returns to these studies to examine how the so-called tarbagan became the subject of investigations regarding plague's ability to survive the harsh winters of the region. The question was related to ideas about 'chronic plague', which in the case of the Siberian marmot were linked to its hibernation between October and April. Using an abundance of visual material, Lynteris argues that, on the one hand, tarbagan burrows, which had been epistemic objects ever since the discovery of the species in 1856, and, on the other hand, marmot hibernation, which had been the focus of scientific investigation in relation to host immunity already by 1902 , were tied together into an epidemiological duet as a result of the emergency of the Manchurian plague epidemic of 1910-1911. There is indeed a crucial metonymic work involved in this tying together the 'mystery of the survival of plague' over winter to marmot hibernation, and marmot underground dwellings. ${ }^{41}$ For the three actants in this network of what following Genese Sodikoff, we may call 'zoonotic semiotics'-latent plague, hibernating marmots, underground burrows - shared and maintained between them an image of 'mystery' 
and occultation which has been key both to epidemiological reasoning regarding infectious diseases and to the 'pandemic imaginary' underlying understandings of zoonosis. ${ }^{42}$ This image of plague taking advantage of unseen biological processes, materialities or infrastructures so it can assume an imperceptible form that would allow it to persevere over either human action against it or environmentally adverse conditions is of course reliant on Pasteurian notions virulence, latency and attenuation. Yet, more than simply illuminating a reiteration of bacteriological doctrine, what the tarbagan example points out to is a pervasive aspect of epidemiological reasoning; for the assumption that, when plague (or indeed any other disease) is not seen, this is because it is 'hiding', is part of what we may call a cynegetic complex in epidemiology.

As John Berger once noted, admittedly in a very different context, a key principle (and, one may add, a mythic structure) of cynegetic worlds is that, 'what has vanished has gone into hiding'. ${ }^{43}$ In the case of epidemiology, as with other cynegetic cosmologies, this implies an ambivalent relation. ${ }^{44}$ On the one hand, microbes are seen as predators of humanity, who lurk and hide so as to better ambush their prey. And on the other hand, as the enduring metaphor of 'virus hunters' amply illustrates, microbes are also seen as humanity's pray - which thus 'hide' to escape being caught and vanquished by us. ${ }^{45}$ As Frédéric Keck has stressed (following Chamayou), '[w]hereas pastoral techniques are asymmetrical, relying on the pastor's superior gaze over the flock manifested by sacrifice, cynegetic techniques are symmetrical, as hunters and prey constantly change perspectives when displayed in rituals'. ${ }^{46}$ Maurits Meerwijk's chapter in the present volume shows that this is indeed a historically pervasive framework, which in the case of mosquitoes is carried over from tropical medicine into Global Health. Comparing the discourses of Ronald Ross and Bill Gates, Meerwijk shows how the cynegetic metaphor comes to encompass not only the pathogens in question but also their vectors. This points out at a transformative ontology underlying epidemiological reasoning, and its obsession with the 'invisibility' of disease, insofar as pathogens are seen, on the one hand, as able to persist by transforming themselves inside non-human animal hosts (by means of attenuation or mutation) and, on the other hand, as able to spread by transforming their hosts into bestial man-hunters. ${ }^{47}$ More than simply blaming non-human animals, in epidemiological reasoning, this double transformative ability configures the former into the loci par excellence of pathogenesis and, at the same time, necessitates techniques of rendering host-pathogen relations visible. 


\section{Visualising Animals as Epidemic Villains}

Visual images of non-human animals have played a historically important role in their configuration as epidemic villains. Since the dawn of bacteriology, the scientific identification and examination of non-human hosts and vectors of infectious diseases have heavily relied on photographic technologies (including microphotography), diagrams and epidemic cartography. ${ }^{48}$ Following Sayer (this volume), animals have been 'fed into a data-focused visual regime', combining photography, mapping, diagrams and statistical graphs, that seeks to establish points of contact, habitats, interspecies boundaries and other forms of what Hannah Brown and Ann $\mathrm{H}$. Kelly have called human/non-human 'material proximities'. ${ }^{49}$ In the context of high-modern epidemiology as well as in today's EID framework, these visualisations are part of a project of mastery aimed not so much at the subjugation of nature, as to the control of humanity's relations with nature. ${ }^{50}$ Diagrammatic images of dissected mosquitoes played a key role in Ronald Ross' examination of the insects as malaria vectors, as, in later years, the microphotography of Anopheles gambiae dissected ovaries would prove an indispensable, Soviet-led method for identifying the capacity of a given mosquito to transmit the malaria plasmodium to humans. ${ }^{51}$ Similarly, Nicholas Evans has shown, in the course of the third plague pandemic, comparative images between healthy and plague-infected rats became standard visual objects in epidemiological investigations and their published reports. ${ }^{52}$

But the visualisation of 'epidemic villains' did not always necessitate their direct representation. In her chapter for this volume, Sayer draws an insightful comparison between two sets of visualising rat control, the first in the English port of Liverpool and the second in British India. In both cases, the actual rats are imperceptible, with the photographic focus being on humans undertaking carefully orchestrated epidemiological work (rat dissection, flea collection); a fact which, in the case of Liverpool, is underlined by the staged poses of the sanitary officers in questions, and, in the case of India, was permeated by colonial racial hierarchies in the representation of lab work. As representations of the relation between pandemic plague, medical science and Empire, these images provide reassuring portraits of control in direct dialogue with the image of objectified rats, described by Evans, thus 'making rats an integral part of plague'. ${ }^{3}$ Similarly, with a focus on this relational aspect of human/non-human mastery and its visual regimes, in the second chapter of this volume Lynteris illustrates how the 
epidemic framing of Siberian marmots as reservoirs of plague in Inner Asia relied on photography and the diagrammatic cartography of their burrows. Comprising in survey photographs of excavated marmot burrows and diagrammatic depictions of burrow systems, the visual regime constructed around this suspected host of plague following the Manchurian plague outbreak of 1910-1911 comes to show, on the one hand, that intrusive practices of epidemiological visualisation were not limited to human dwellings, but also included those of non-human animals (photographing the marmot burrows required their prior excavation), and, on the other hand, that the visual framing of 'epidemic villains' is not limited to the representation of their role as spreaders of diseases. ${ }^{54}$

At the same time, the popularisation of the identity of specific mammals, birds and insects as disease spreaders has and continues to be mediated by their visual representation through photography, film and illustration. Photographs of 'wet markets' in South China during and in the aftermath of the 2003 SARS pandemic have been shown to incorporate a key principle of 'epidemic photography': the depiction of animal-related spaces as potential ground zeros of the 'next pandemic'. 55 The practice of the public vilification of non-human animals and the framing of contact spaces between them and humans as infection hotspots was established for the first time in the course of anti-malarial and anti-yellow fever campaigns in the first decades of the twentieth century, but also during complex public health operations against plague in the context of the third plague pandemic (1894-1959) when the dreaded disease was often visually personified as the rat. ${ }^{56}$ Indeed, quite often, the image of animals as enemies of humanity assumed anthropomorphic aspects, which under a colonialist gaze, involved racist inflections. In Australian newspaper illustrations, for example, plague-carrying rats were depicted having Chinese faces, thus both making an aetiological connection between plague and China (plague as an 'Oriental disease' arriving from China, by Chinese migrants) and fostering broader Sinophobic bigotry at the time. ${ }^{57}$ In his examination of the framing of 'tiger mosquitoes' (Aedes aegypti and Aedes albopictus) in this volume, Meerwijk explores the rich visual culture supporting progressive framings of the specific mosquito species as infectious enemies of humanity. In a striking example, Meerwijk shows how the diagrammatic juxtaposition of a mosquito and a tiger was used in a public health poster, meant to underline the predatory, man-eating qualities of Aedes mosquitos. Pointing at a pervasive tendency to talk about and visualise mosquitoes in terms of great predators (tigers, sharks) or 'enemies of humanity' (terrorists, vampires, 
prostitutes), Meerwijk elucidates the work of the fusion between military, cynegetic and sexual metaphors and visual tropes employed in the depiction of mosquitoes across epidemiological paradigms.

This is all the more important as the visualisation of animals as 'epidemic villains' was a trope that found application and success beyond epidemiology and public health. Non-human animals were charismatic protagonists of political caricatures since the turn of the eighteenth century. In particular, Lukas Englemann notes, "The "political bestiary", as Gombrich calls the long tradition of depicting political issues through animal characters, acquired widespread popularity in the nineteenth century. The meaning many animals inhabited could be easily exploited to convey strong messages and almost always suggested degradation'. ${ }^{58}$ What changed at the turn of the nineteenth century was the introduction of a new aspect in the use of animals in caricature: their infectious nature. With political discourse utilising more and more medical terms at the time, the use of the visual form of the infectious animal to portray one's political enemies became an exemplary field of vilification. To mention only one example, in the course of the Moscow Trials, soon after the Soviet state prosecutor, Andrey Vyshinsky, publicly pledged 'to stamp out the accursed vermin' who 'should be shot down like rabid dogs', the prolific cartoonist of the Pravda, Boris Efimov (who was present at the trial), produced a striking caricature of Leon Trotsky and Nikolai Bukharin as a two-headed rabid dog held on the leash by the hand of the Gestapo. ${ }^{59}$

However, as Engelmann has shown in his examination of caricatures in the course of the 1900 plague outbreak in San Francisco, the aim of depicting animals in the context of epidemic crises has not been limited to practices of blaming the former as spreaders or reservoirs of disease. In fact, animals were also used to critique and ridicule bacteriology itself. For example, in the case of San Francisco, newspaper caricatures used animals to portray bacteriology 'as a science that formulated its judgments through experiments with animals, not in the treatment of people'. ${ }^{60}$ By visualising laboratory animals as 'vermin and pest', Englemann argues, bacteriology was portrayed as 'a wasteful expenditure of public funds' and 'the medical laboratory was stripped of its progressive potential and instead appeared as an infliction of damage on the public good'. ${ }^{61}$ At the same time, as Dawn Day Biehler has shown in her monograph on pests in twentieth-century US history, images of disease hosts, like rats, have also been used for subaltern purposes, such as the campaigns by the Black Panther Party in the 1960s1970s against slumlords and the living conditions in African American 
neighbourhoods. ${ }^{62}$ For example, Biehler argues, the well-known illustration by Emory Douglas, 'Black Misery! Ain't We Got Right to the Tree of Life?', 'constrast[ed] with images of women afraid of rats; the woman's grip on the rat suggests determination, courage and fury'. ${ }^{63}$ Here, the rat represented the unhygienic, exploitative and pestilential conditions imposed by white capital on working-class African Americans, and the latter's determination to face up to this social injustice. The prolific use of images of non-human animals as 'epidemic villains' in diverse fields of social practice as public health campaigns, political propaganda, the critique of bacteriology and subaltern critiques of power and domination, points at the importance placed on the infectious nature or potential of animals both as a reality and as a metaphor in the modern world. However, whether it is to convey a threat to the national body, or to mock science, the use of these images also points at the fascination and discomfort of moderns towards non-human agency.

Underlining how epidemiology and public health emerged in relation to, and continue to be informed by framings of non-human animals as epidemic villains, the chapters in this volume explore the layered political, symbolic and epistemic investments of non-human animals, as these have become rhetorically and visually enabled in distinct ways over the past 150 years. Whether it is stray dogs as spreaders of rabies in colonial and contemporary India, bushmeat as the source of Ebola in West Africa, mosquitoes as vectors of malaria, dengue, Zika and yellow fever in the Global South, or rats and marmots as hosts of plague during the third pandemic, this volume shows framings of non-human animals to be entangled in local webs of signification and, at the same time, to be global agents of modern epidemic imaginaries.

Acknowledgements Research leading to this chapter was funded by a European Research Council Starting Grant under the European Union's Seventh Framework Programme/ERC grant agreement no. 336564 for the project Visual Representations of the Third Plague Pandemic (University of Cambridge and University of St Andrews). I would like to thank Lukas Engelmann, Nicholas Evans, Branwyn Poleykett, Maurits Meerwijk and Abhijit Sarkar for enduring and stimulating discussions on animals as 'epidemic villains' in the course of the project, and the participants of the project's fourth annual conference, Assembling Epidemics: Disease, Ecology and the (Un) natural, at the University of Cambridge's Centre for Research in the Humanities, Arts and Social Sciences (CRASSH) for their contribution to the project's discussion of this topic. Short passages in the section 'Disease Spreaders' of 
this Introduction were previously published in: Christos Lynteris, 'Zoonotic Diagrams: Mastering and Unsettling Human-Animal Relations'. Journal of the Royal Anthropological Institute NS 23:3 (July 2017): 463-485.

\section{Notes}

1. J. Fairhead, 'Technology, Inclusivity and the Rogue Bats and the War Against "the Invisible Enemy". Conservation and Society 16:2 Special Section: Green Wars (2018): 170-180. On civet cats see M. Zhan, 'Civet Cats, Fried Grasshoppers, and David Beckham's Pajamas: Unruly Bodies After SARS'. American Anthropologist 107:1 (March 2005): 31-42.

2. C. Caduff, The Pandemic Perbaps: Dramatic Events in a Public Culture of Danger (Berkeley, CA: University of California Press, 2015); N. B. King, 'The Scale Politics of Emerging Diseases'. Osiris 19 (2004): 62-76.

3 . For a broader historical review of the role of animals in human health from One Health perspectives, see A. Woods, M. Bresalier, A. Cassidy, and R. Mason Dentinger (eds.), Animals and the Shaping of Modern Medicine: One Health and Its Histories (London: Palgrave Macmillan). For a critique of One Health's interspecies perspective, see S. J. Hinchliffe, 'More Than One World More Than One Health: Reconfiguring Inter-Species Health'. In C. Herrick and D. Reubi (eds.), Global Health and Geographical Imaginaries, pp. 159-175 (Oxon and New York: Routledge, 2017).

4. I am using animal-borne diseases here as a term inclusive of zoonotic and vector-borne diseases.

5. N. Pemberton, 'The Rat-Catcher's Prank: Interspecies Cunningness and Scavenging in Henry Mayhew's London'. Journal of Victorian Culture 19 (2014): 520-535.

6. M. Fissell, 'Imagining Vermin in Early Modern England'. History Workshop Journal 47 (1999): 1-29. For an influential example of the rat being described as disease-free, see J. Rodwell, The Rat: Its History \& Destructive Character (London: Routledge \& Co, 1858).

7. C. M. Cipolla, Cristofano and the Plague: A Study in the History of Public Health in the Age of Galileo (Berkeley and Los Angeles, CA: University of California Press, 1973).

8. C. Renny, Medical Report on the Mabamurree in Gurbwal in 1849-50 (Agra: Secundra Orphan Press, 1851). The rat would become suspect of carrying plague for the first time during the inaugural outbreak of the third plague pandemic, in 1894 Hong Kong, with another decade elapsing before the universal acceptance of the link between the animal and human plague. The first scientific study showing the role of the rat and its flea in the propagation of plague was: P. L. Simond, 'La propagation de la peste'. Annales de l'Institut Pasteur 12 (1898): 625-687. 
9. Fissell, 'Imagining Vermin in Early Modern England', p. 1.

10. R. Danton, The Great Cat Massacre and Other Episodes in French Cultural History (New York: Vintage Books, 1985); K. Thomas, Religion and the Decline of Magic: Studies in Popular Beliefs in Sixteenth and Seventeenth Century England (Weidenfeld and Nicholson, 1971).

11. Fissell, 'Imagining Vermin in Early Modern England', pp. 11, 6.

12. L. Cole, Imperfect Creatures: Vermin, Literature, and the Sciences of Life, 1600-1740 (University of Michigan Press, 2016), p. 4.

13. Ibid., p. 23. On vermin and the poor, see P. Camporesi, Bread of Dreams: Food and Fantasy in Early Modern Europe, translated by David Gentilcore (Chicago: University of Chicago Press, 1989); K. Raber, Animal Bodies, Renaissance Culture (University of Pennsylvania Press, 2013); L. Woodbridge, Vagrancy, Homelessness and English Renaissance Literature (Urbana: University of Illinois Press, 2001). On the wider implication of poverty, plague and 'filth', see John Henderson, "'Filth is the Mother of Corruption". Plague, the Poor and the Environment in Early Modern Florence'. In L. Engelmann, J. Henderson, and C. Lynteris (eds.), Plague and the City, pp. 69-90 (London and New York: Routledge, 2018).

14. Cole, Imperfect Creatures.

15. W. Riguelle, 'Que la peste soit de l'animal! La législation à l'encontre des animaux en période d'épidémies dans les villes des Pays-Bas méridionaux et de la principauté de Liège (1600-1670)'. In R. Luglia (ed.), Sales bêtes! Mauvais herbes! 'Nuisible', une notion en débat, pp. 109-124 (Paris: Presses Universitaires de Rennes, 2018). Cole (2016) notes that in the seventeenth century, ideas of animal-associated miasma were entangled with ideas about animals as demonic companions of witches.

16. Riguelle, 'Que la peste soit de l'animal!'; On ideas of miasma emanating from butchered meat see D. R. Carr, 'Controlling the Butchers in Late Medieval English Towns'. The Historian 70:3 (Fall 2008): 450-461; M. Dorey, 'Controlling Corruption: Regulating Meat Consumption as a Preventative to Plague in Seventeenth-Century London'. Urban History 36:1 (May 2009): 24-41; C. Rawcliffe, "“Great Stenches, Horrible Sights and Deadly Abominations": Butchery and the Battle Against Plague in Late Medieval English Towns'. In L. Engelmann, J. Henderson, and C. Lynteris (eds.), Plague and the City, pp. 18-38 (London and New York: Routledge, 2018).

17. D. S. Barnes, 'Cargo, "Infection," and the Logic of Quarantine in the Nineteenth Century'. Bulletin of the History of Medicine 88:1 (2014): 75-10.

18. M. Harrison, Climates and Constitutions: Health, Race, Environment and British Imperialism in India 1600-1850 (Oxford: Oxford University Press, 1999). On miasma as 'poison', see S. Bhattacharya, M. Harrison, and M. Worboys, Fractured States: Smallpox, Public Health and Vaccination Policy in British India, 1800-1947 (Hyderabad: Orient Longman, 2005); 
D. Arnold, Toxic Histories: Poison and Pollution in Modern India (Cambridge: Cambridge University Press, 2016).

19. Rabies is probably the first disease to be observed as connecting humans and non-humans animals. As Kathleen Kete has shown, the modern transformation of this connection, before the dawn of bacteriology, was fostered by a sexualisation of the disease, which rendered it comparable to uncontrollable impulses or lust. Commenting on Kete's work, Linda Kalof writes: 'since nymphomania and uncontrollable sexual desire in men were considered the result of prolonged sexual abstinence, so also was rabies the spontaneous outcome of canine sexual frustration'; K. Kete, The Beast in the Boudoir: Petkeeping in Nineteenth-Century Paris (Berkeley, CA: University of California Press, 1994); L. Kalof, Looking at Animals in Human History (London: Reaktion Books, 2007), p. 143.

20. K. Brown and D. Gilfoyle, 'Epizootic Diseases in the Netherlands, 17132002'. In K. Brown and D. Gilfoyle (eds.), Healing the Herds: Disease, Livestock Economies, and the Globalization of Veterinary Medicine, pp. 1941 (Athens, OH: Ohio University Press, 2010); D. Gilfoyle, 'Veterinary Research and the African Rinderpest Epizootic: The Cape Colony, 18961898'. Journal of Southern African Studies 29(1) (2003): 133-154; S. Kheraj, 'The Great Epizootic of 1872-73: Networks of Animal Disease in North American Urban Environments'. Environmental History 23:3 (2018): 495-521; S. Mishra, Beastly Encounters of the Raj: Livelihoods, Livestock and Veterinary Health in India, 1790-1920 (Manchester: Manchester University Press, 2015); L. Wilkinson, Animals and Disease: An Introduction to the History of Comparative Medicine (Cambridge: Cambridge University Press, 1992); A. Woods, 'From Coordinated Campaigns to Watertight Compartments: Diseased Sheep and Their Investigation in Britain, c.1880-1920'. In A. Woods, M. Bresalier, A. Cassidy, and R. Mason Dentinger (eds.), Animals and the Shaping of Modern Medicine: One Health and Its Histories, pp. 71-117 (London: Palgrave Macmillan, 2018).

21. K. Bardosh, 'Unpacking the Politics of Zoonosis Research and Policy'. In K. Bardosh (ed.), One Health. Science, Politics and Zoonotic Disease in Africa, pp. 1-20 (London and New York: Routledge, 2016); K. Beumer, 'Catching the Rat: Understanding Multiple and Contradictory HumanRat Relations as Situated Practices'. Society \& Animals 22 (2014): 8-25; N. H. Evans, 'Blaming the Rat? Accounting for Plague in Colonial Indian Medicine'. Medicine, Anthropology, Theory 5:3 (2018): 15-42; M. Gandy, 'The Bacteriological City and Its Discontents'. Historical Geography 34 (2006): 14-25; R. Deb Roy, Malarial Subjects: Empire, Medicine and Nonhumans in British India, 1820-1909 (Cambridge: Cambridge University Press, 2017).

22. C. E. Rosenberg, 'What Is an Epidemic? AIDS in Historical Perspective'. Daedalus 118:2 Living with AIDS (Spring 1989): 1-17. 
23. See, for example, C. Keiner, 'Wartime Rat Control, Rodent Ecology, and the Rise and Fall of Chemical Rodenticides'. Endaevour 29:3 (2005): 119-125; A. H. Kelly and J. Lezaun, 'Urban Mosquitoes, Situational Publics, and the Pursuit of Interspecies Separation in Dar es Salaam'. American Ethnologist 41:2 (2014): 368-383; M. Lyons, The Colonial Disease: A Social History of Sleeping Sickness in Northern Zaire, 1900-1940 (Cambridge: Cambridge University Press, 1992); C. C. Mavhunga, The Mobile Workshop: The Tsetse Fly and African Knowledge Production (Cambridge, MA: MIT Press, 2018); P. B. Mukharji, 'Cat and Mouse: Animal Technologies, Trans-Imperial Networks and Public Health from Below, British India, c. 1907-1918'. Social History of Medicine 31:3 (2017): 510-532; B. Poleykett, 'Building Out the Rat: Animal Intimacies and Prophylactic Settlement in 1920s South Africa'. American Anthropological Association (Engagement) (2017). https://aesengagement. wordpress.com/2017/02/07/building-out-the-rat-animal-intimaciesand-prophylactic-ssettlement-in-1920s-south-africa/; K. Sayer, 'The "Modern" Management of Rats: British Agricultural Science in Farm and Field During the Twentieth Century'. British Journal for the History of Science 2 (2017): 235-263; Michael G. Vann, 'Of Rats, Rice, and Race: The Great Hanoi Rat Massacre, an Episode in French Colonial History'. French Colonial History 4 (2003): 191-203.

24. P. Descola, Beyond Nature and Culture, translated by J. Lloyd (Chicago, IL: Chicago University Press, 2013). For a more detailed discussion of this process, see C. Lynteris, 'Zoonotic Diagrams: Mastering and Unsettling Human-Animal Relations'. Journal of the Royal Anthropological Institute NS 23:3 (July 2017): 463-485; M. Vaughan, Curing Their Ills: Colonial Power and African Illness (Stanford, CA: Stanford University Press, 1991).

25. F. Keck and C. Lynteris, 'Zoonosis: Prospects and Challenges for Medical Anthropology'. Medical Anthropology Theory 5:3 (2018): 1-14. For a systematic critique of the current spillover frameworks, see V. Narat, L. Alcayna-Stevens, S. Rupp, and T. Giles-Vernick, 'Rethinking Human-Nonhuman Primate Contact and Pathogenic Disease Spillover'. EcoHealth 14 (2017): 840-850.

26. King, 'The Scale Politics of Emerging Diseases'.

27. Caduff, The Pandemic Perhaps; Frédéric Keck, 'Avian Preparedness: Simulations of Bird Diseases and Reverse Scenarios of Extinction in Hong Kong, Taiwan, and Singapore'. Journal of the Royal Anthropological Institute NS 24:2 (2018): 330-347; A. Lakoff, Unprepared: Global Health in a Time of Emergency (Berkeley, CA: The University of California Press, 2017).

28. Caduff, The Pandemic Perhaps; Carlo Caduff, 'Great Anticipations'. In A. H. Kelly, F. Keck, and C. Lynteris (eds.), The Anthropology of Epidemics, pp. 43-58 (London and New York: Routledge, 2019). 
29. C. Lynteris, Human Extinction and the Pandemic Imaginary (London and New York: Routledge, in print).

30. W. Petersen, Outbreak (Hollywood: Warner Brothers Pictures; color, 127 mins, 1995). For discussion, see K. Ostherr, Cinematic Prophylaxis: Globalization and Contagion in the Discourse of World Health (Durham, NC: Duke University Press, 2005); Fairhead, 'Technology, Inclusivity and the Rogue Bats and the war Against "the Invisible Enemy".

31. P. W. Ewald, 'Cultural Vectors, Virulence and the Emergence of Evolutionary Epidemiology'. Oxford Surveys in Evolutionary Biology 5 (1988): 215-245. As Fairhead argues, this entanglement of 'native culture' with 'rogue animals' has the effect of transferring the status of the 'rogue' to the 'culture' in question; Fairhead, 'Technology, Inclusivity and the Rogue Bats and the War Against "the Invisible Enemy"'. See also M. Leach and I. Scoones, 'The Social and Political Lives of Zoonotic Disease Models: Narratives, Science and Policy'. Social Science \& Medicine 88 (2013): 10-17.

32. For a discussion of disgust and animal disease, see A. L. Olmstead, Arresting Contagion. Science, Policy and Conflicts Over Animal Disease Control (Cambridge, MA: Harvard University Press, 2015); S. D. Jones, 'Mapping a Zoonotic Disease: Anglo-American Efforts to Control Bovine Tuberculosis Before World War I'. Osiris, 2nd Series, 19, Landscapes of Exposure: Knowledge and Illness in Modern Environments (2004): 133-148. It needs to be noted here that, following Fissell, the emergence of the early modern notion of 'vermin' was not associated with disgust-something that points to the introduction of this affective and sensory structure in the nineteenth century in association to miasmatic ideas about 'dirt' and 'filth'; Fissell, 'Imagining Vermin in Early Modern England'.

33. Colónia de Angola, Serviço permanente de prevenção e combate à peste bubónica no sul de Angola: relatório 1933 (Lisboa: Agência Geral das Colónias, 1934).

34. Gilberto Hochman, The Sanitation of Brazil: Nation, State, and Public Health, 1889-1930, translated by Diane Grosklaus Whitty (Champaign IL: University of Illinois Press, 2016).

35. M. Honigsbaum, “"Tipping the Balance”: K. F. Meyer, Latent Infections, and the Birth of Modern Ideas of Disease Ecology'. Journal of the History of Biology 49:2 (2016): 261-309.

36. Hergé, Tintin au Congo (Brussels: Le Petit Vingtième, 1931).

37. Honigsbaum, “"Tipping the Balance”, p. 278.

38. Ibid.

39. Evans, 'Blaming the Rat?'.

40. Honigsbaum, "'Tipping the Balance"'. See in particular: C. S. Elton, 'Plague and the Regulation of Numbers in Wild Mammals.' The Journal of Hygiene 24:2 (1925): 138-163. 
41. E. Dujardin-Beaumetz and E. Mosny, 'Évolution de la peste chez la Marmotte pendant l'hibernation'. Comptes rendus hebdomadaires des séances de l'Académie des sciences 155 (1912): 329-332, p. 332.

42. G. M. Sodikoff, 'Zoonotic Semiotics: Plague Narratives and Vanishing Signs in Madagascar'. Medical Anthropology Quarterly 33:1 (2019): 4259. For a more detailed examination of zoosemiotics in the case of marmots, see C. Lynteris, 'Speaking Marmots, Deaf Hunters: Animal-Human Semiotic Breakdown as the Cause of the Manchurian Pneumonic Plague of 1910-11'. In M. Tønnessen and K. Tüür (eds.), The Semiotics of Animal Representations (Amsterdam: Rodopi, 2014). On the pandemic imaginary: Lynteris, Human Extinction and the Pandemic Imaginary.

43. J. Berger, Here Is Where We Meet (London: Bloomsbury, 2005), p. 141.

44. On the ambivalence as applies to hunters and gatherers, see R. Willerslev, Soul Hunters: Hunting, Animism, and Personhood Among the Siberian Yukaghirs (Berkeley, CA: The University of California Press, 2007).

45. On virus hunters, see Guillaume Lachenal, 'Lessons in Medical Nihilism. Virus hunters, Neoliberalism and the AIDS Pandemic in Cameroon'. In P. Wenzel Geissler (ed.), Para-States and Medical Science: Making African Global Health, pp. 103-141 (Durham, NC: Duke University Press, 2015).

46. Keck, 'Avian Preparedness', p. 332. On Chamayou's theory, see Grégoire Chamayou, Manhunts: A Philosophical History, translated by S. Rendall (Princeton: Princeton University Press, 2012).

47. For colonial medical framings of the transformative ability of plague, see C. Lynteris, 'Pestis Minor: The History of a Contested Plague Pathology'. Bulletin of the History of Medicine 93:1 (Spring 2019): 55-81; C. Lynteris, 'A Suitable Soil: Plague's Breeding Grounds at the Dawn of the Third Pandemic'. Medical History 61:3 (June 2017): 343-357. For a discussion of the mythic ability of pathogens to transform their hosts into man-hunters, see C. Lynteris, 'The Epidemiologist as Culture Hero: Visualizing Humanity in the Age of "the Next Pandemic". Visual Anthropology 29:1 (2016): 36-53.

48. On diagrams and the configuration of zoonosis, see Lynteris, 'Zoonotic Diagrams'; M. Ziegler, 'The Evolution of Ebola Zoonotic Cycles'. Contagion (November 11, 2017). https://contagions.wordpress.com/2017/ $11 / 11 /$ the-evolution-of-ebola-zoonotic-cycles/.

49. H. Brown and A. H. Kelly, 'Material Proximities and Hotspots: Toward an Anthropology of Viral Hemorrhagic Fevers'. Medical Anthropology Quarterly 28:2 (2014): 280-303.

50. Lynteris, Human Extinction and the Pandemic Imaginary.

51. A. H. Kelly, 'Seeing Cellular Debris, Remembering a Soviet Method'. Visual Anthropology, Special Issue: Medicine, Photography and Anthropology 29:2 (2016): 133-158.

52. Evans, 'Blaming the Rat?'. 
53. Ibid., p. 33.

54. On the practice of intrusive epidemic photography as regards human dwellings, see R. Peckham, 'Plague Views. Epidemic, Photography and the Ruined City'. In L. Engelmann, J. Henderson, and C. Lynteris (eds.), Plague and the City, pp. 92-115 (London and New York: Routledge, 2018).

55. C. Lynteris, 'The Prophetic Faculty of Epidemic Photography: Chinese Wet Markets and the Imagination of the Next Pandemic'. Visual Anthropology, Special Issue: Medicine, Photography and Anthropology 29:2 (2016): $118-132$.

56. Evans, 'Blaming the Rat?'. This 'global visual economy' was so pervasive in fact so as to lead to a retrospective diagnosis of the presence of rats in paintings such as Nicholas Poussin's 1665 The Plague of Ashdod as evidence of a pre-bacteriological knowledge of this zoonotic connection; for a critique, see S. Barker, 'Poussin, Plague and Early Modern Medicine'. The Art Bulletin 86:4 (2004): 659-689.

57. C. Lynteris. 'Yellow Peril Epidemics: The Political Ontology of Degeneration and Emergence'. In F. Billé and S. Urbansky (eds.), Yellow Perils: China Narratives in the Contemporary World (Honolulu: Hawaii University Press, 2018).

58. L. Engelmann, 'A Plague of Kinyounism: The Caricatures of Bacteriology in 1900 San Francisco’. Social History of Medicine (2018). https://doi. org/10.1093/shm/hky039, p. 15.

59. S. M. Norris, 'The Sharp Weapon of Soviet Laughter: Boris Efimov and Visual Humor'. Russian Literature 74:1-2 (2013): 31-62.

60. Engelmann, 'A Plague of Kinyounism', p. 18.

61. Ibid., p. 25.

62. D. D. Biehler, Pests in the City: Flies, Bedbugs, Cockroaches, and Rats (Washington, DC: University of Washington Press, 2013).

63. Ibid., p. 146. 